\author{
Izabela Kołodziejczyk-Olczak \\ Department of Labour and Social Policy \\ University of Lodz
}

\title{
Reactive and Proactive Age Management Strategies in Polish Companies - Research Results
}

\begin{abstract}
Population aging is an objective process that will be unavoidable for the foreseeable future, because demographic changes cannot be quickly reversed. Populations are aging in Poland and other countries, particularly highly urbanised and industrialised ones. As a result, in addition to having to cope with the numerous challenges of globalisation, internationalisation, tertiarisation, informatisation, growth of competition and innovation, as well as changing consumption patterns and customs, organisations also face the effects of aging.

Successive types of age management strategies and practices have arisen from how age management has been understood and handled, which shows that organisations develop linearly. Two early types are examples of reactive strategies that emerged in response to the requirements of the business environment. Other strategies, which I refer to in the paper as 1 st, $2 \mathrm{nd}$, and 3rd generation strategies, are proactive. In this paper I classify age-management strategies adopted by Polish employers using an indicator that I designed. The study results demonstrate that while Polish employers differ in how they approach the problem of age and how they manage it in the instrumental and functional sphere, in the institutional sphere they are only somewhat advanced and differentiated. „Soft” age management is a necessary part of a company's social model, and makes it possible for many stakeholders to benefit. The economic model, on the other hand, seems insufficient, particularly in the long term.
\end{abstract}

Keywords: age management, ageing society, older worker, active ageing, human resource management. 


\section{Introduction}

Today's organisations are changing in numerous ways. In addition they must cope with the myriad challenges they face in globalisation, internationalisation, tertiarisation, informatisation, the growth of competition and innovation, changing consumption patterns and customs. Organisations also face the impact of aging.

The phenomenon of population aging is an objective process - it is inevitable for the foreseeable future, because demographic changes are not reversible in the short term. This phenomenon affects Poland and other countries, especially those that are highly urbanised and industrialised. An even greater number of Polish companies will come up against its effects in the future.

The purpose of this paper is to present age-management strategies currently adopted by Polish companies and to outline the necessary changes and improvements companies will have to make in the future.

\section{Theoretical Characteristics of Age Management}

The issue of age management appeared in the literature less than twenty years ago. Polish writers and researchers began to discuss it only a few years ago. It is most often discussed by Polish researchers in human resource management, including R. Jaros, P. Krajewski, M. Mackiewicz (Osoby po 45. roku życia... 2010, p. 50), B. Urbaniak and I. Wieczorek (2007, p. 11), J. Liwiński and U. Sztanderska (2010a), and T. Schimanek (2010a, p. 48). The term "age management" may refer to various dimensions of HRM within an organisation with a clear focus on aging (Walker 1997) but it can also refer to policy or collective bargaining (Walker 2005, p. 685). The term is sometimes associated with strategic management or diversity management: " (...) it is an element of human resource management, and more specifically: an element of diversity management. It consists in the implementing of a variety of actions that allow for a more rational and efficient use of human resources in enterprises by addressing the needs and abilities of workers of all ages" (Liwiński \& Sztanderska 2010b, p. 3). Some approaches suggest using the term "age diversity management" in this context as a more appropriate one (Kulicka 2012, p. 13). Generally, age management instruments combat age barriers and (or) promote age diversity, and they help create an environment in which individual employees are able to exploit their potential without being disadvantaged due to age (Naegele \& Walker 2006, p. 3). In the context of strategic management, thanks to age management instruments we can bridge the gap between current and desired resources (Fig. 1). 


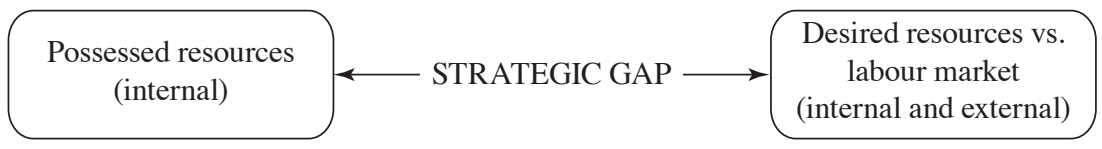

Fig. 1. Strategic Gap of Human Resources

Source: the author's own study.

J. Ilmarinen (2005) has a complex approach to age management, presenting it as part of strategic management, which is closely related to company strategy (Fig. 2).

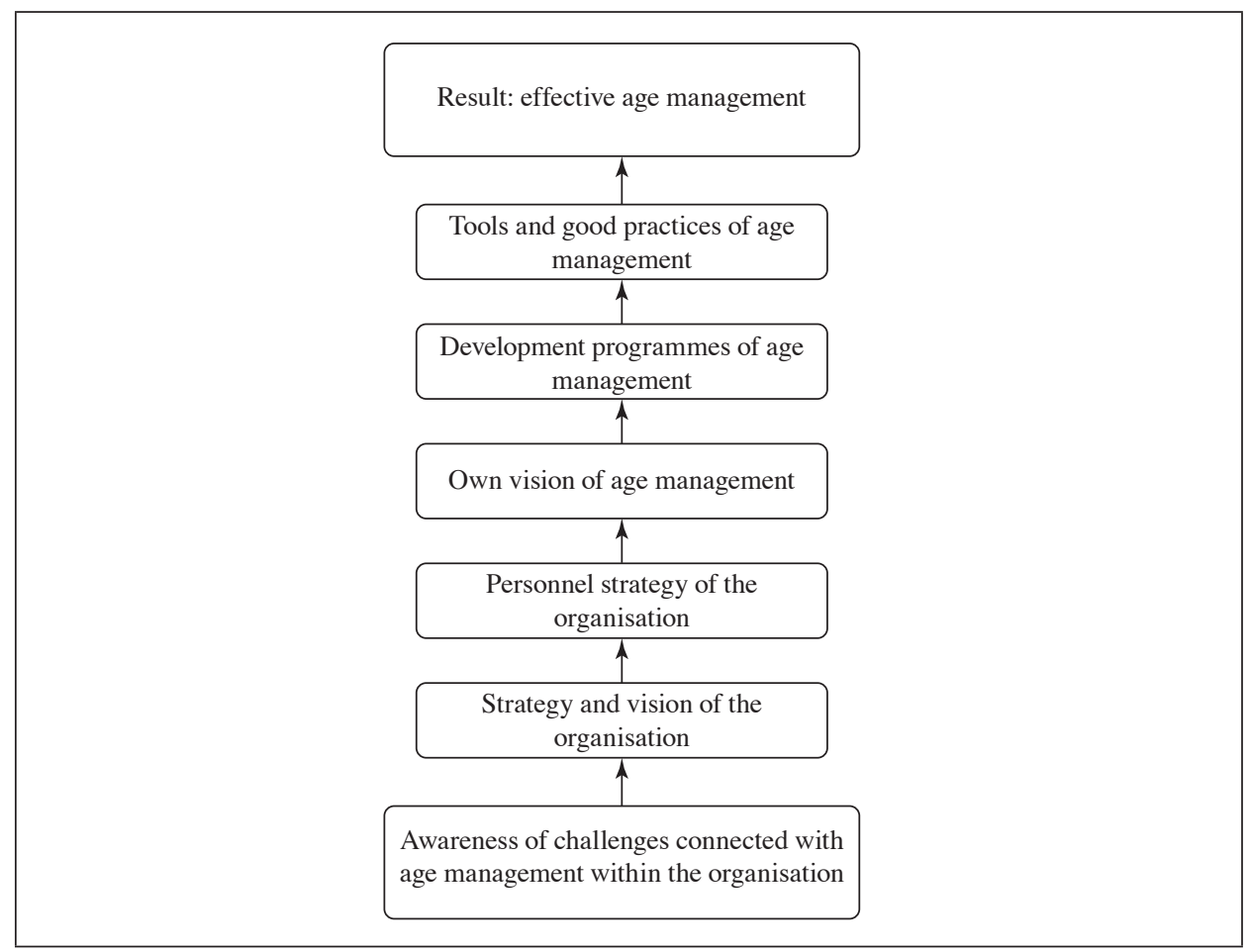

Fig. 2. Effective Age Management as a Result

Source: prepared on the basis of (Ilmarinen 2005, p. 235).

Awareness of the challenges associated with age management is at the core of Ilmarinen's process. This awareness in turn shapes HR strategy and individual age management instruments. In any case, a vision of age management, according to which all planned and executed actions are to create effective age management, is key. 


\section{Age Management Strategies}

\subsection{Age Management Strategies - The Concept of Wallin and Hussi}

Experts at the Finnish Work Environment Fund, M. Wallin and T. Hussi are the authors of probably the first typology of age management strategies. The two have made a significant contribution to the dissemination of theoretical thought on society aging and the development of broadly defined practices of age management (Wallin \& Hussi 2011).

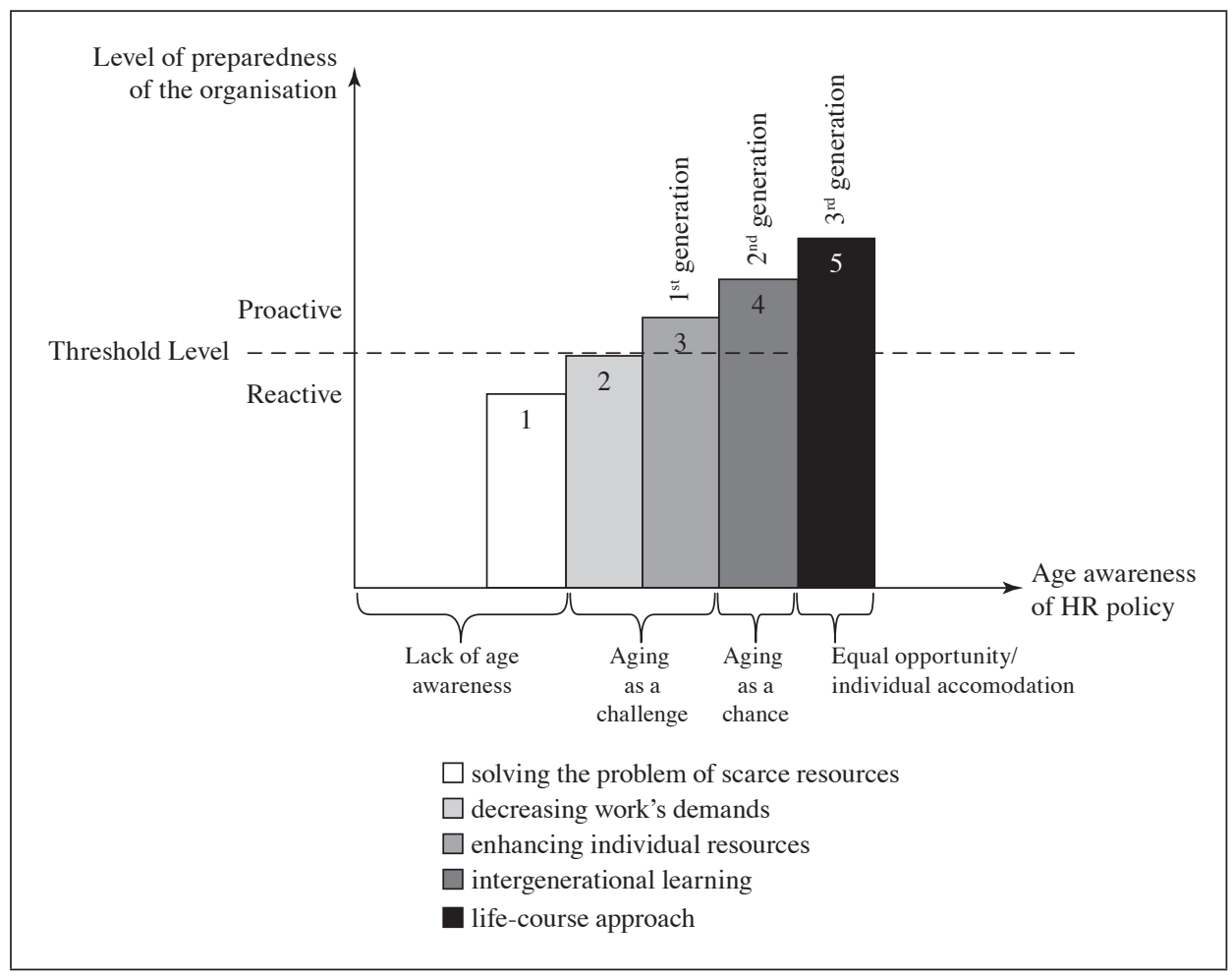

Fig. 3. Age Management Strategies Types

Source: based on (Wallin \& Hussi 2011).

The typology ${ }^{1}$ grew out of a 2011 analysis of case studies on the best practices of age management. 136 cases of 200 available in the Eurofound database were analysed. They contain descriptions of small, medium and large organisations in

1 Typology should be understood as scheduling, see www.pwn.pl Knowledge Portal. 
both the private and public sectors. Conclusions from the analysis of best practices say that two variables have the most important influence on age management: attitude towards aging and the level of readiness for action. In order to examine the ways used to manage age using two trajectories -1 ) the preparation level of the organisation and 2) the role of age in HR policies - five different types were created. They were called "solving the problem of scarce resources", "decreasing work's demands", "enhancing individual resources", "intergenerational learning", and "life-course approach" (Fig. 3).

The types of management practices are essentially hierarchical, resulting from the maturation of organisations to next solutions. Organisations are at different stages of coping with the challenges of the current business environment and selecting specific solutions. The types of strategies and practices of age management currently being used have grown out, and continue to grow out of how previous measures and strategies were understood, indicating a linear maturation. The first two types are reactive strategies, built as a response to the demands of the business environment. The other strategies are proactive approaches that create 1st, 2nd and 3rd generation strategies.

\section{Reactive Strategy: Solving the Problem of Scarce Resources}

Companies using this strategy did not realise the problems associated with aging, but it resulted rather from the needs of the business and economic organisation. The most common problem in companies that used a reactive strategy was the lack of skilled workers, so organisations faced with limited resources created innovative solutions. These most often consisted in recruiting older, unemployed workers and training them and employing former, retired employees as extra hands to work in periods of increased production. Employment of older workers often required adapting tasks to their physical capabilities, by reducing their workload or working time. Older workers were used out of necessity or because they were seen as a strategic resource. Although these strategies were favourable for older workers, there were also by-products of innovative solutions in age management organisations (Wallin \& Hussi 2011).

\section{Reactive Strategy: Decreasing the Demands of Work}

Organisations using this strategy recognise age as a challenge. It was believed that older workers have problems with further work on their positions, they are less physically fit and less resistant, they have a higher risk of diseases and therefore generally require more attention and flexibility on the part of the employer. They constituted a potential threat to productivity and generated the risk of higher labour costs. Measures used to solve these problems were meant to reduce the requirements of physical labour: tasks during a shift were organised in such a way 
as to ensure workload uniformity, while older workers were permanently assigned to work requiring less physical strength, were not assigned to the night shift, and were offered extra days off. Ergonomics and tasks were controlled by implementing appropriate modifications. Guidance for older workers concerning their careers was also introduced in order to facilitate the preparation of plans for further employment or a smooth transition into retirement. These solutions were meant to improve the ability of older workers to continue working (Wallin \& Hussi 2011).

\section{1st Degree Proactive Strategy: Enhancing Individual Resources}

This type of strategy is based on proactive age management measures applied in enterprises, recognising age as a challenge. It is implemented in response to the need to enhance the ability of older workers to work and improve the working environment, and a greater risk of loss of competence and health among them. The strategy of strengthening personal resources is used not only to reduce labour requirements, but also to release available resources. The most common measures taken to enhance the ability of older workers to work including promoting health, medical rehabilitation, healthy meals, and creating co-worker support groups for people who want to stop smoking or lose weight. An active lifestyle was promoted by providing company gyms, thus enabling physical exercise during working hours, and partially refunding the cost of physical activity. The ability of older workers to perform work was also increased as a result of constant education. Training programmes tailored to the needs of adults were used as well as counselling sessions and employee and supervisor talks on development. Such an approach is based on the belief that older employees are able to constantly acquire new skills and that it is possible to improve their welfare through a healthy lifestyle. The approach to age management described here can be considered the first generation of age management practices (Wallin \& Hussi 2011).

\section{2nd Degree Proactive Strategy: Intergenerational Learning}

Companies using this strategy took into account the productive aging of employees recognising and appreciating the skills and experience of older employees. The companies took steps to exploit the expertise of mature employees as consultants, coordinators, trainers and mentors. These measures were primarily aimed at ensuring the transfer of know-how to younger employees.

They ensured a reduction in the work-load while at the same time improving the effectiveness of learning. It is also worth noting that knowledge was passed in both directions. The work of experienced seniors with younger employees allowed the artistry of the profession to be passed along by mature employees and IT skills to be showcased by younger employees. The age-management measures were also used to create a positive attitude to age in the organisation. Steps were also taken to improve the work environment and promote the health and well-being 
of employees. Running training sessions to revise competencies without any age restrictions, mentoring, parallel execution of tasks and the use of older employees as internal coaches were additional important solutions. By employing this strategy, the company came to understand the demographic changes taking place and fully understood the processes of aging, leading to physical, psychological and social changes. These processes were perceived as parts of a very individualised course, which, in weakening some characteristics, such as physical strength, at the same time compensates for deficiencies arising, inter alia, from high efficiency, which enables employees to cope at work. Tacit knowledge - that is, knowledge acquired as a result of a lot of experience - was used and appreciated. Such a supportive environment encouraged the various generations to interact, which was beneficial for both the older and younger employees and ensured a continuous, two-way flow of knowledge. This approach to age management can be considered second-generation age management.

\section{3rd Degree Proactive Strategy: Life-course Approach}

This approach is based on proactive age management measures combined with the overall sensitivity of businesses to diversity. The motivation behind this strategy was not concern about aging employees, but the desire to ensure that all have equal opportunities. Companies using this strategy recruited people from different ethnic backgrounds and ages as well as applied horizontal and vertical transfers to ensure the full diversity of employee teams. These companies led an anti-discrimination policy, and therefore offered flexible working conditions to all employees regardless of their age, gender, or other special features. The "life-course approach" consisted in assigning flexibility to employees according to the their knowledge and career stage, thus providing welfare at work. Making management more sensitive was of great importance. All employees were covered with flexible solutions and flexible working hours tailored to their individual needs. Such elasticity makes it possible to carry out professional work and manage the balance between private and professional life, while also participating in training and in professional work at different career stages. The course of life approach provides for covering all employees, regardless of their age, with age management practices (Wallin \& Hussi 2011).

Typologies are a theoretical introduction to the presentation of the results of studies on age-management strategies in Polish organisations.

\subsection{Age Management Strategies - A Study of Polish Employers}

To classify age management strategies used among Polish employers, a database of 1011 employers from the "Equal opportunities in the labour market 
for people aged $50+{ }^{2}$ study was used. On the basis of one of the survey questions, organisations based on traditional knowledge were distinguished and in the two sub-groups an analysis was continued, recognising that ${ }^{3}$ :

- traditional organisations are entities which declare that their assets are primarily material resources (buildings, land, machinery and the like);

- knowledge-based organisations are entities which declare that their assets are mainly intangible resources (staff expertise and know-how, to name two).

This approach reduced the sample size to 928 subjects, though the sample still meets the conditions of representativeness ${ }^{4}$. The results can therefore be generalised for the population of employers in Poland. The results were analysed using the chi-square test of independence or Fisher's exact test.

The type of strategy, and hence the applied age-management instruments, selected depend largely on the perception of mature employees, their competence, health, fitness, and perception of the environment, changes and future challenges. Two perspectives - traditional and knowledge-based organisations - determine the organisational activities that are planned and modified as required.

In the present study of age-management strategies among Polish employers, I use an age-management indicator I developed for the purpose. The composite indicator is composed of partial indicators as presented in Tables 1-5. I examined the level of fulfilment in organisations (both sections) and the level of significance of all partial indicators. Intensity characteristics are marked with a colour (significant receivables are marked with a darker colour). Presenting the results this way makes it possible to illustrate the execution of different types of age-management strategies by Polish employers ${ }^{5}$.

2 "Equal opportunities in the labour market for people aged 50+" is a system project implemented by the Human Resources Development Centre in partnership with the University of Lodz for the Ministry of Labour and Social Policy. The project is co-financed by the European Social Fund under the Human Capital Operational Programme. From 2010-2013 I served as manager for the coordination of activities at the University of Lodz.

${ }^{3}$ In the Leader in Human Resources Management contest companies are analysed taking into account a close criterion: traditional production companies and production companies using advanced technologies and traditional services and knowledge pursuant to (Urbaniak \& Bohdziewicz 2011-2012). The author of this paper is an auditor in this contest.

${ }_{4}$ The number of individuals in the limited sample is sufficiently large and, moreover, the sample randomness test (test series) leads to the conclusion that, due to the key for the research, included as criteria for stratification, the sample is random (random test series verifies the hypothesis that the selection of items from the population in the sample was random, which is the same as saying that the test variable (sample) is random (Malarska 2005, p. 143). At the same time, one has to notice that the two conditions of representativeness of the sample (sufficient sample size and its randomness (Wiktorowicz 2009, p. 37) have been met, which allows one to generalise about the population.

${ }^{5}$ Excerpt elaborated in (Kołodziejczyk-Olczak 2014). 
Table 1. The Strategy for Scarce Resources (Indications in Percentage), $N=928$

\begin{tabular}{|c|c|c|c|}
\hline $\begin{array}{c}\text { Synthetic } \\
\text { characteristics }\end{array}$ & Partial indicator & $\begin{array}{c}\text { Traditional } \\
\text { organisation }\end{array}$ & $\begin{array}{l}\text { Organisation } \\
\text { based on } \\
\text { knowledge }\end{array}$ \\
\hline \multirow{15}{*}{$\begin{array}{l}\text { Recruiting older } \\
\text { employees, } \\
\text { the unemployed } \\
\text { and retirees }\end{array}$} & $\begin{array}{l}\text { Hiring people with pension entitlements over the } \\
\text { past five years }\end{array}$ & $33.8^{*}$ & $22.7^{*}$ \\
\hline & Allocating overtime hours to employees $45+$ first & $8.0^{*}$ & $1.5^{*}$ \\
\hline & $\begin{array}{l}\text { Proposing employees with pension entitlements } \\
\text { remain employed }\end{array}$ & $20.0^{*}$ & $11.1^{*}$ \\
\hline & $\begin{array}{l}\text { Proposing individuals with pension entitlements } \\
\text { remain employed because it is not possible to } \\
\text { replace them }\end{array}$ & $11.5^{*}$ & $2.7^{*}$ \\
\hline & $\begin{array}{l}\text { Paying attention to professional experience of simi- } \\
\text { lar nature when hiring employees }\end{array}$ & $42.9^{*}$ & $31.5^{*}$ \\
\hline & Mature employees working on a three-shift basis & $5.7^{*}$ & $0.6^{*}$ \\
\hline & Employing mature employees on a full-time basis & $100.0^{*}$ & $79.0^{*}$ \\
\hline & $\begin{array}{l}\text { Employing mature employees on the basis of } \\
\text { a contract of indefinite duration }\end{array}$ & $91.3^{*}$ & $82.5^{*}$ \\
\hline & Cooperating with self-employed individuals & $41.2^{*}$ & $63.5^{*}$ \\
\hline & $\begin{array}{l}\text { Not employing older people, because none applied } \\
\text { in the recruitment process }\end{array}$ & $54.1^{*}$ & $70.9^{*}$ \\
\hline & Re-employing, if necessary, retired employees & 45.4 & 52.1 \\
\hline & Employing an employee because he was available & 11.5 & 16.2 \\
\hline & $\begin{array}{l}\text { Offering employment on the basis of a contract } \\
\text { of employment for a specified period }\end{array}$ & 15.8 & 21.6 \\
\hline & $\begin{array}{l}\text { Offering employment on the basis of a civil law } \\
\text { contract }\end{array}$ & 9.1 & 9.5 \\
\hline & $\begin{array}{l}\text { Offering employment for traineeships or under } \\
\text { a different assisted form }\end{array}$ & 0.0 & 1.6 \\
\hline
\end{tabular}

* Statistically significant differences or relations were marked if the $p$-value was lower than the level of significance $\alpha=0.05$.

Source: the author's own research.

Scarce resource strategies were implemented mainly by traditional organisations. Recognising the shortage of personnel, they offered jobs to mature people and employed them on a full-time basis to work on a three-shift basis and overtime. At the same time, thanks to providing employment for an indefinite period of time, they got at the motivational nature of employment, because mature employees value job security. Examples of elements assigned to this type of age-management strategy achieved significantly more often by knowledge-based organisations may indicate their greater flexibility in how they do business. For example, they contracted with the people who run their own business and did not use discriminatory practices - 
they did not employ anyone for lack of candidates, but because they instead opted for retirees. The desired candidates had to be available.

Table 2. Strategy for Decreasing the Demands of Work (Indications in Percent), $N=928$

\begin{tabular}{|c|c|c|c|}
\hline $\begin{array}{c}\text { Synthetic } \\
\text { characteristics }\end{array}$ & Partial indicator & $\begin{array}{c}\text { Traditional } \\
\text { organisation }\end{array}$ & $\begin{array}{l}\text { Organisation } \\
\text { based on } \\
\text { knowledge }\end{array}$ \\
\hline \multirow{15}{*}{$\begin{array}{l}\text { Higher risk of } \\
\text { the reduction } \\
\text { efficiency } \\
\text { organisation of } \\
\text { work } \\
\text { selection of } \\
\text { posts / time to } \\
\text { the possibility } \\
\text { of employees }\end{array}$} & $\begin{array}{l}\text { Noticing the natural decline in physical fitness of } \\
\text { people aged } 45+\end{array}$ & $80.5^{*}$ & 77.8* \\
\hline & $\begin{array}{l}\text { Recognising the limited possibility of moving } \\
\text { mature employees to other jobs }\end{array}$ & $84.6^{*}$ & $82.1^{*}$ \\
\hline & $\begin{array}{l}\text { The use of workforce planning, taking age into } \\
\text { account }\end{array}$ & $18.8^{*}$ & $10.8^{*}$ \\
\hline & Using work time planning with regard to age & $18.8^{*}$ & $13.4^{*}$ \\
\hline & $\begin{array}{l}\text { Suggesting major changes to enhance the employ- } \\
\text { ment of mature people in less mentally aggravating } \\
\text { jobs }\end{array}$ & $10.8^{*}$ & $4.8^{*}$ \\
\hline & Employing mature persons on a full-time basis & 88.8 & 87.7 \\
\hline & Choosing forms of work with regard to age & 19.2 & 15.9 \\
\hline & $\begin{array}{l}\text { Suggesting major changes to enhance the employ- } \\
\text { ment of mature people in less stressful jobs }\end{array}$ & 22.3 & 18.6 \\
\hline & $\begin{array}{l}\text { Suggesting major changes to enhance the employ- } \\
\text { ment of mature people and supplying special } \\
\text { equipment at the workplace }\end{array}$ & 2.3 & 1.8 \\
\hline & $\begin{array}{l}\text { Suggesting major changes to enhance the employ- } \\
\text { ment of mature people and adapting the workplace } \\
\text { to the employee's ability }\end{array}$ & 4.6 & 3.6 \\
\hline & $\begin{array}{l}\text { Suggesting major changes to enhance the employ- } \\
\text { ment of mature people equals a smaller number of } \\
\text { hours }\end{array}$ & $13.8^{*}$ & $28.4^{*}$ \\
\hline & $\begin{array}{l}\text { Suggesting major changes to enhance the employ- } \\
\text { ment of mature people equals flexible working } \\
\text { hours }\end{array}$ & $11.5^{*}$ & $30.5^{*}$ \\
\hline & $\begin{array}{l}\text { Suggesting major changes to enhance the employ- } \\
\text { ment of mature people equals the possibility to } \\
\text { work at home }\end{array}$ & $8.8^{*}$ & $18.5^{*}$ \\
\hline & Hiring individuals aged $45+$ on a part-time basis & 21.4 & 24.3 \\
\hline & $\begin{array}{l}\text { Suggesting major changes to enhance the employ- } \\
\text { ment of mature people equals a more convenient } \\
\text { organisation of work }\end{array}$ & 8.5 & 10.2 \\
\hline
\end{tabular}

* Statistically significant differences or relations were marked if the $p$-value was lower than the level of significance $\alpha=0.05$.

Source: the author's own research. 
The strategy of decreasing work's demands was the domain of traditional organisations. Knowledge-based organisations actually implemented this strategy to increase their flexibility. They offered part-time work for mature people, and declared that the most important changes that could be made to achieve greater inclusion of workers included allowing flexible hours, reducing the number of hours, and the ability to work from home.

Table 3. The Enhancing Individual Resources Strategy (Indications in Percent), $N=928$

\begin{tabular}{|c|c|c|c|}
\hline $\begin{array}{c}\text { Synthetic } \\
\text { characteristics }\end{array}$ & Partial indicator & $\begin{array}{l}\text { Traditional } \\
\text { organisation }\end{array}$ & $\begin{array}{l}\text { Organisation } \\
\text { based on } \\
\text { knowledge }\end{array}$ \\
\hline \multirow{10}{*}{$\begin{array}{l}\text { The promotion } \\
\text { of healthy and } \\
\text { active lifestyles, } \\
\text { rehabilitation } \\
\text { medicine, } \\
\text { constant edu- } \\
\text { cation }\end{array}$} & The use of individual wages for effects at work & $66.3^{*}$ & $74.7^{*}$ \\
\hline & $\begin{array}{l}\text { Expressing the opinion that if employees lost their } \\
\text { jobs they could definitely find a similar one }\end{array}$ & $66.5^{*}$ & $74.8^{*}$ \\
\hline & $\begin{array}{l}\text { The use of health bonuses in the form of preventive } \\
\text { vaccination campaigns }\end{array}$ & $19.2^{*}$ & $24.9 *$ \\
\hline & The use of a free health bonus & $6.2^{*}$ & $1.2^{*}$ \\
\hline & $\begin{array}{l}\text { Expressing the opinion that employees aged } 45+\text { are } \\
\text { as interested in participating in training as the rest }\end{array}$ & 12.7 & 13.0 \\
\hline & Offering passes to a swimming pool as a bonus & 35.6 & 42.5 \\
\hline & Offering passes to a fitness club as a bonus & 1.8 & 1.9 \\
\hline & Offering additional health insurance as a bonus & 1.8 & 1.9 \\
\hline & $\begin{array}{l}\text { Expressing the opinion that employees aged } 45+\text { are } \\
\text { more interested in participating in trainings than } \\
\text { others }\end{array}$ & 8.5 & 6.9 \\
\hline & $\begin{array}{l}\text { Using individualised wages to bring about desired } \\
\text { effects at work }\end{array}$ & 4.2 & 4.2 \\
\hline
\end{tabular}

* Statistically significant differences or relations were marked if the $p$-value was lower than the level of significance $\alpha=0.05$.

Source: the author's own research.

The 1st degree management strategy is already clearly being realised by organisations based on knowledge. Rewarding on the basis of competence, making rewards dependent on individual employee effects, to which high competences will certainly contribute, organisations use pro-efficiency rewarding. They perceive employees without bias, emphasising their willingness to receive training and the strong opportunities they enjoy on the labour market in the event of potential job loss. They also use health bonuses that can help keep mature employees in better shape and promote health through an active lifestyle and leisure sport activities. 
Table 4. The Intergenerational Learning Strategy (Indicators in Percent), $N=928$

\begin{tabular}{|c|c|c|c|}
\hline $\begin{array}{c}\text { Synthetic } \\
\text { characteristics }\end{array}$ & Partial indicator & $\begin{array}{c}\text { Traditional } \\
\text { organisation }\end{array}$ & $\begin{array}{l}\text { Organisation } \\
\text { based on } \\
\text { knowledge }\end{array}$ \\
\hline \multirow{13}{*}{$\begin{array}{l}\text { Use the exper- } \\
\text { tise of consul- } \\
\text { tants, coaches, } \\
\text { and mentors; } \\
\text { knowledge } \\
\text { transfer } \\
\text { between mature } \\
\text { and younger } \\
\text { workers; } \\
\text { training to } \\
\text { improve skills; } \\
\text { appreciation of } \\
\text { competence; } \\
\text { training for } \\
\text { managers on } \\
\text { topics related to } \\
\text { aging }\end{array}$} & $\begin{array}{l}\text { Using methods aimed at retaining knowledge in } \\
\text { the form of contacts with pensioners with exper- } \\
\text { tise in connection with retiring employees }\end{array}$ & $35.4^{*}$ & $46.5^{*}$ \\
\hline & $\begin{array}{l}\text { Hiring people with pension entitlements due to } \\
\text { the unique qualifications of employees }\end{array}$ & $3.8^{*}$ & $58.1^{*}$ \\
\hline & $\begin{array}{l}\text { Using training methods that encourage the } \\
\text { exchange of experiences: mentoring, coaching }\end{array}$ & $32.7^{*}$ & $47.7^{*}$ \\
\hline & Using team work with teams of varied ages & $43.1^{*}$ & $67.3^{*}$ \\
\hline & Applying knowledge management & $56.2^{*}$ & $68.0^{*}$ \\
\hline & Using mirroring competence & $53.5^{*}$ & $64.5^{*}$ \\
\hline & Participation in EU programmes & $11.1^{*}$ & $5.3^{*}$ \\
\hline & Using the relay system & $51.9 *$ & $38.0 *$ \\
\hline & $\begin{array}{l}\text { Proposing employees with pension rights remain } \\
\text { employed because they could teach others }\end{array}$ & $4.2^{*}$ & $1.1^{*}$ \\
\hline & Preparing successors & 36.0 & 36.9 \\
\hline & $\begin{array}{l}\text { Preparing documentation as a knowledge-reten- } \\
\text { tion method }\end{array}$ & 58.8 & 53.3 \\
\hline & Offering age management training & 2.3 & 1.7 \\
\hline & $\begin{array}{l}\text { Showing interest by employees aged } 45+\text { in parti- } \\
\text { cipating in trainings, but in the role of trainers }\end{array}$ & 0 & 0 \\
\hline
\end{tabular}

* Statistically significant differences or relations were marked if the $p$-value was lower than the level of significance $\alpha=0.05$.

Source: the author's own research.

The intergenerational knowledge transfer strategy is used significantly more often by organisations based on knowledge. They use various forms of retention of knowledge in the organisation, and match people based on their unique qualifications and expertise, and use coaching and mentoring, which is certainly one of the components that produces successors. Traditional organisations also appreciate this kind of strategy, as they suggest pensioners remain at work to teach others. These employees then use the relay system, which consists in their transferring knowledge to the next employee and helping them adapt to their newly occupied workplace.

Based on accepting the diversity of work organisation, and offering the employee the choice of flexible forms of work, the life-course strategy is implemented significantly more often by knowledge-based organisations. Traditional organisations excelled only in organising trainings, which are certainly 
related to the use of training co-financed from EU funds. Managing diversity, age, and work-life balance are common and fashionable workshop topics.

Table 5. The Life-course Strategy (Indicators in Percent), $N=928$

\begin{tabular}{|c|c|c|c|}
\hline $\begin{array}{c}\text { Synthetic } \\
\text { characteristics }\end{array}$ & Partial indicator & $\begin{array}{c}\text { Traditional } \\
\text { organisation }\end{array}$ & $\begin{array}{c}\text { Organisation } \\
\text { based on } \\
\text { knowledge }\end{array}$ \\
\hline \multirow{18}{*}{$\begin{array}{l}\text { Diversity; } \\
\text { equal opportu- } \\
\text { nities; } \\
\text { welfare; } \\
\text { work-life } \\
\text { balance; } \\
\text { personal } \\
\text { resources } \\
\text { (self-reliance, } \\
\text { health, compe- } \\
\text { tence) }\end{array}$} & $\begin{array}{l}\text { Using team work in teams of different ages for } \\
\text { mature workers }\end{array}$ & $43.1^{*}$ & $67.3^{*}$ \\
\hline & $\begin{array}{l}\text { Expressing the opinion that employees aged } 45+ \\
\text { prefer to work in teams of different ages }\end{array}$ & $27.9^{*}$ & $36.3^{*}$ \\
\hline & $\begin{array}{l}\text { Allocating tasks in accordance with the preferences } \\
\text { of workers }\end{array}$ & $5.4^{*}$ & $10.8^{*}$ \\
\hline & $\begin{array}{l}\text { Assigning tasks according to their level of difficulty } \\
\text { and requirements of the job }\end{array}$ & $7.7^{*}$ & $14.6^{*}$ \\
\hline & $\begin{array}{l}\text { Proposing individuals with pension entitlements } \\
\text { remain in the company because of their unique } \\
\text { qualifications }\end{array}$ & $3.8^{*}$ & $58.1^{*}$ \\
\hline & $\begin{array}{l}\text { Proposing individuals with pension entitlements } \\
\text { remain in the company due to a stated desire to } \\
\text { work longer }\end{array}$ & 34.6 & $41.9^{*}$ \\
\hline & $\begin{array}{l}\text { Equal treatment of employees in the event of over- } \\
\text { time work }\end{array}$ & $45.1^{*}$ & $68.0^{*}$ \\
\hline & Using knowledge management & $56.2^{*}$ & $68.0^{*}$ \\
\hline & Using a health bonus & 12.7 & 13.0 \\
\hline & $\begin{array}{l}\text { Expressing the opinion that employees aged } 45+ \\
\text { who have lost their job would get a similar position } \\
\text { based on their competences }\end{array}$ & 23.5 & 25.2 \\
\hline & Offering help to redundant employees aged $45+$ & 0.0 & 3.2 \\
\hline & $\begin{array}{l}\text { Ignoring age while reinforcing the opinion that } \\
\text { results are what counts }\end{array}$ & 95.4 & 95.8 \\
\hline & Conducting CSR training & 6.5 & 6.9 \\
\hline & Individualising work schedules & 19.7 & 24.7 \\
\hline & Conducting training on diversity management & $19.5^{*}$ & $9.3^{*}$ \\
\hline & Conducting training on age management & 2.3 & 1.7 \\
\hline & $\begin{array}{l}\text { Providing training on how to manage the balance } \\
\text { between work and life (WLB) }\end{array}$ & 12.6 & 8.4 \\
\hline & $\begin{array}{l}\text { Allocating tasks in accordance with employee } \\
\text { efficiency (productivity) }\end{array}$ & 31.9 & 30.3 \\
\hline
\end{tabular}

* Statistically significant differences or relations were marked if the $p$-value was lower than the level of significance $\alpha=0.05$.

Source: the author's own research. 
The indicator takes into account only statistically significant differences between traditional knowledge-based organisations and presents hybrid age management strategies employed by Polish organisations (Table 6).

Table 6. Hybrid Age-management Strategies of Polish Companies (Only Statistically Significant Differences)

\begin{tabular}{|c|c|c|c|}
\hline & "Hard-soft" age management & $\begin{array}{l}\text { Traditional } \\
\text { organisation }\end{array}$ & $\begin{array}{l}\text { Organisation } \\
\text { based on } \\
\text { knowledge }\end{array}$ \\
\hline & $\begin{array}{l}\text { Hiring people with pension entitlements over the } \\
\text { past five years }\end{array}$ & $33.8^{*}$ & $22.7^{*}$ \\
\hline & Allocating overtime hours to employees $45+$ first & $8.0^{*}$ & $1.5^{*}$ \\
\hline & $\begin{array}{l}\text { Proposals to remain in employment directed at per- } \\
\text { sons with pension entitlements }\end{array}$ & $20.0^{*}$ & $11.1^{*}$ \\
\hline HARD AGE & $\begin{array}{l}\text { Proposals to remain in employment directed at } \\
\text { persons with pension entitlements because it is not } \\
\text { possible to replace them }\end{array}$ & $11.5^{*}$ & $2.7^{*}$ \\
\hline $\begin{array}{l}\text { GEMENT } \\
\text { They employ }\end{array}$ & $\begin{array}{l}\text { Paying attention to professional experience of a simi- } \\
\text { lar nature when hiring employees }\end{array}$ & $42.9^{*}$ & $31.5^{*}$ \\
\hline & Offering training on diversity management & $19.5^{*}$ & $9.3^{*}$ \\
\hline when they & Participation in EU programmes & $11.1^{*}$ & $5.3^{*}$ \\
\hline need them; & Making use of the relay system & $51.9^{*}$ & $38.0^{*}$ \\
\hline $\begin{array}{l}\text { they train } \\
\text { with the } \\
\text { benefit of EU }\end{array}$ & $\begin{array}{l}\text { Proposals to remain in employment directed at } \\
\text { a person with pension entitlements because he or she } \\
\text { could teach others }\end{array}$ & $4.2^{*}$ & $1.1^{*}$ \\
\hline and take & Making use of work time planning with regard to age & $18.8^{*}$ & $13.4^{*}$ \\
\hline additional & Using workforce planning, taking age into account & $18.8^{*}$ & $10.8^{*}$ \\
\hline measures to & $\begin{array}{l}\text { Using health bonuses in the form of preventive vac- } \\
\text { cination campaigns }\end{array}$ & $6.2^{*}$ & $1.2^{*}$ \\
\hline disease; & Mature employees working on a three-shift basis & $5.7^{*}$ & $0.6^{*}$ \\
\hline ergonomi- & Employing mature employees on a full-time basis & $100.0^{*}$ & $79.0^{*}$ \\
\hline $\begin{array}{l}\text { cally healthy } \\
\text { facilities; }\end{array}$ & $\begin{array}{l}\text { Employing mature employees on the basis of a con- } \\
\text { tract of indefinite duration }\end{array}$ & $91.3^{*}$ & $82.5^{*}$ \\
\hline & $\begin{array}{l}\text { Being aware of the natural decline in physical fitness } \\
\text { of people aged } 45+\end{array}$ & $80.5^{*}$ & $77.8^{*}$ \\
\hline & $\begin{array}{l}\text { Recognising the limited possibility of moving } \\
\text { mature employees to other jobs }\end{array}$ & $84.6^{*}$ & $82.1^{*}$ \\
\hline & $\begin{array}{l}\text { Suggesting major changes to enhance the employ- } \\
\text { ment of mature people in less mentally aggravating } \\
\text { jobs }\end{array}$ & $10.8^{*}$ & $4.8^{*}$ \\
\hline
\end{tabular}


Table 6 cnt'd

SOFT, FLEX-

IBLE AGE

MANAGE-

MENT

They see

diversity and

subjectively

treat mature

employees,

they appre-

ciate exper-

tise and offer

a work-life

balance based

on flexibility

and remote

work
"Hard-soft" age management

Cooperating with self-employed contractors

Not employing older people because none applied in the recruitment process

Suggesting major changes to enhance the employment of mature people equals a smaller number of hours

Suggesting major changes to enhance the employment of mature people equals flexible working hours

Suggesting major changes to enhance the employment of mature people equals the possibility to work at home

Using team work and teaming individuals of different ages

Allocating tasks in accordance with the preferences of workers

Assigning tasks according to their level of difficulty and the requirements of the job

Employing people with pension entitlements due to the unique qualifications of employees

Treating employees equally when it comes to overtime work

Using knowledge management

Using methods aimed at retaining knowledge in the form of contacts with pensioners with expertise in connection with employees retiring

\begin{tabular}{|l|c|c|}
\hline Using remuneration for competence & $66.3^{*}$ & $74.7^{*}$ \\
\hline $\begin{array}{l}\text { Using individualised wages for individual effects at } \\
\text { work }\end{array}$ & $66.5^{*}$ & $74.8^{*}$ \\
\hline $\begin{array}{l}\text { Expressing the opinion that if employees lost their jobs } \\
\text { they could definitely find a similar one }\end{array}$ & $19.2^{*}$ & $24.9^{*}$ \\
\hline $\begin{array}{l}\text { Expressing the opinion that employees aged 45+ prefer } \\
\text { to work with teams made up of different ages }\end{array}$ & $27.9^{*}$ & $36.3^{*}$ \\
\hline $\begin{array}{l}\text { Proposing that a person with pension entitlements } \\
\text { remain with the company following the employee's } \\
\text { stated desire to work longer }\end{array}$ & 34.6 & 41.9 \\
\hline Equal treatment of employees working overtime & $45.1^{*}$ & $68.0^{*}$ \\
\hline Using competence mirroring & $53.5^{*}$ & $64.5^{*}$ \\
\hline
\end{tabular}

* Statistically significant differences or relations were marked if the $p$-value was lower than the level of significance $\alpha=0.05$.

Source: the author's own research. 
Although traditional Polish organisations often applied reactive age management strategies and their knowledge-based counterparts proactive age management ones, the hybridism of solutions should be noted. Two of the strategies - scarce resources, and reduced requirements - constitute hard management. Companies that use these strategies employ mature employees at the time of need, train with the benefit of EU financing, use bonuses to protect employees against illnesses and use ergonomic and organisational facilities for the elderly. "Hard" age management is the domain of traditional organisations. Knowledge-based organisations due to the fact that they see the diversity and treat mature employees as individuals, and value their expertise, recognising the need to strike a balance between work and life based on flexibility and remote work, use "soft" age management. A part of the social enterprise model, soft age management enables companies to achieve value for many stakeholders, as the economic and financial model appears to be insufficient, particularly in the long term. The division into "hard" and "soft" management comes from the classification developed by J. Storey (1992).

Age management strategies in Poland are presented in Fig. 4.

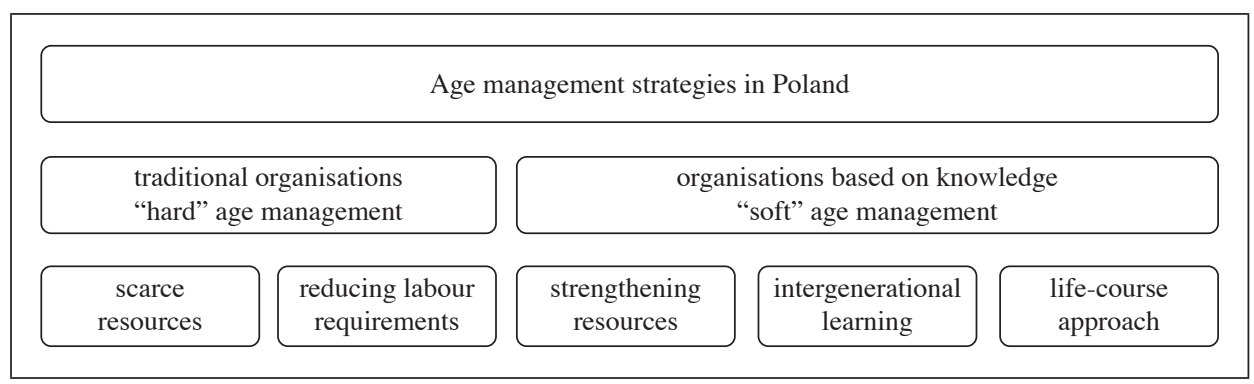

Fig. 4. Age Management Strategies in Poland

Source: the author's own research.

In contrast, the areas assigned to the "soft" and "hard" approach are shown in Fig. 5.

"Hard" age management strategies focus mainly on economic benefits and motivations and those employers who use them seem to get results from implementing them fairly quickly. They are a derivative of the current situation in companies today and the deficit in human resources, organisational necessities as it were. "Soft" strategies are based on an entirely different philosophy. They focus more on social aspects of management, with the benefits showing the company to be diverse, flexible, willing to listen to stakeholders' needs and consider a long-term perspective and the possibilities of achieving deferred success. This model focuses on such aspects of management as communication, 


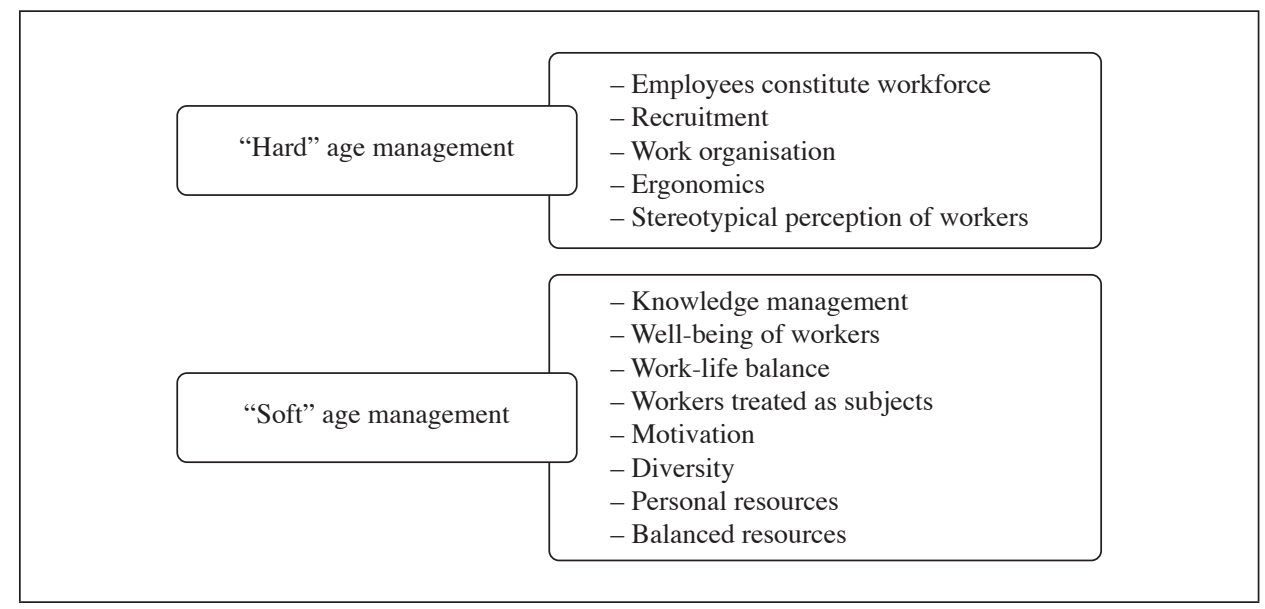

Fig. 5. Areas of "Soft" and "Hard" Age Management

Source: the author's own research.

motivation, involvement and leadership. In this respect, an employee is treated as a subject and a partner.

\section{Summary}

After looking at the subject literature and numerous study results, it is clear that Polish entrepreneurships do not, as yet, commonly employ age management. In terms of perceiving mature employees and age management tools used in practice as well as overall "climate", they have, however, advanced to an intermediate level and are quite diversified. The study presented in this paper has shown that adopting the 1st, 2nd and 3rd generation age management strategies are more frequently used by knowledge-based organisations while the strategies of "solving the problem of scarce resources" and "reducing labour requirements" ("hard" age management) are more often implemented by traditional companies.

Such model approach to age management in the form of hard and soft strategies may raise the question of the divisibility of both approaches. However, despite certain simplifications, their ordering character cannot be denied.

All companies would do well to employ a strategic approach to age management founded on comprehensive benefit-related attitudes, creating values for the organisation and the well-being of mature people. Both national and local regulations as well as promotional campaigns should focus on a soft approach to age management. An analysis of the best practices used by knowledge-based organisations would be very useful. 


\section{Bibliography}

Ilmarinen J. (2005), Towards a Longer Worklife! Ageing and the Quality of Worklife in the European Union, Finnish Institute of Occupational Health, Ministry of Social Affairs and Health, Helsinki.

Kołodziejczyk-Olczak I. (2014), Zarzqdzanie pracownikami dojrzałymi. Wyzwania i problemy, Wydawnictwo Uniwersytetu Łódzkiego, Łódź.

Kulicka S. (2012), Praktyczny poradnik zarzq̨dzania różnorodnościq wiekowa, Caritas Polska, Warszawa.

Liwiński J., Sztanderska U. (2010a), Wstępne standardy zarzq̨dzania wiekiem w przedsiębiorstwach, PARP, Warszawa.

Liwiński J., Sztanderska U. (2010b), Zarzq̨dzanie wiekiem w przedsiębiorstwie, Uniwersytet Warszawski, Warszawa.

Malarska A. (2005), Statystyczna analiza danych wspomagana programem SPSS, SPSS, Kraków.

Naegele G., Walker A. (2006), A Guide to Good Practice in Age Management, Office for Official Publications of the European Communities.

Osoby po 45. roku życia na rynku pracy Lubelszczyzny (2010), R. Jaros, P. Krajewski, M. Mackiewicz (eds), Fundacja CBOS, Warszawa.

Schimanek T. (2010), Co to jest zarzqdaanie wiekiem? (in:) Aktywizacja zawodowa osób $50+i$ zarzqdzanie wiekiem. Informacje użyteczne dla instytucji rynku pracy, Akademia Rozwoju Filantropii w Polsce, Warszawa.

Storey J. (1992), Developments in the Management of Human Resources: An Analytical Review, Blackwell, Cambridge.

Urbaniak B., Bohdziewicz P. (2011-2012), Human Resource Management. Creating Modernity, IPiSS, Warsaw.

Urbaniak B., Wieczorek I. (2007), Zarzqdzanie wiekiem (in:) B. Urbaniak (ed.), Pracownicy 45+ w naszej firmie, UNDP, Warszawa.

Walker A. (1997), Combating Age Barriers in Employment - A European Research Report, European Foundation, Dublin.

Walker A. (2005), The Emergence of Age Management in Europe, "International Journal of Organisational Behaviour", vol. 10(1).

Wallin M., Hussi T. (2011), Best Practices in Age Management - Evaluation of Organisation Cases, Final report, Finnish Work Environment Fund.

Wiktorowicz J. (2009), Organisation Survey (in:) W. Starzyńska (ed.), Fundamentals of Statistics, Difin, Warsaw.

\section{Reaktywne i proaktywne strategie zarządzania wiekiem w polskich organizacjach - wyniki badań}

Zjawisko starzenia się społeczeństwa jest procesem mającym obiektywny charakter, jest nieuniknione w dającej się przewidzieć przyszłości, gdyż zmiany demograficzne nie są odwracalne w krótkim czasie. Zjawisko to dotyka Polskę i inne kraje, szczególnie te wysoko zurbanizowane i uprzemysłowione. Obok licznych wyzwań związanych ze sprostaniem procesom takim jak globalizacja, umiędzynarodowienie, tercjalizacja, informaty- 
zacja, wzrost konkurencji czy innowacyjności, zmiany w konsumpcji i obyczajach, organizacje muszą zmierzyć się ze skutkami starzenia.

Strategie zarządzania wiekiem przyjęte przez polskich pracodawców zostały w artykule sklasyfikowane z wykorzystaniem wskaźnika zarządzania wiekiem zaprojektowanego przez autorkę badań. Wyniki analiz pokazują, że polskie przedsiębiorstwa jeszcze nie stosują powszechnie zarządzania wiekiem. Zarówno w kontekście postrzegania dojrzałych pracobiorców, jak i stosowanych w praktyce instrumentów zarządzania wiekiem oraz ogólnego „klimatu” są one średnio zaawansowani i zróżnicowani. Zauważalne jest przyjmowanie strategii zarządzania wiekiem I, II i III generacji raczej przez organizacje oparte na wiedzy, natomiast strategie „rozwiązywanie problemu skąpych zasobów” oraz „obniżanie wymogów pracy”, czyli „twarde” zarządzanie wiekiem, wdrażane są raczej przez przedsiębiorstwa tradycyjne.

Słowa kluczowe: zarządzanie wiekiem, starzenie się społeczeństwa, pracownik dojrzały, aktywne starzenie się, zarządzanie zasobami ludzkimi. 